1 Bーb 5 ショウジョウバエと狫癌运子研究

西田充巧（爱知がんセ・研・放射穆）

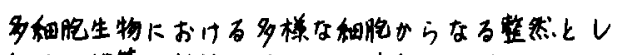

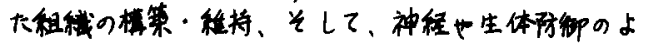
うな高次能の笔现のたのには、高度下说達した和

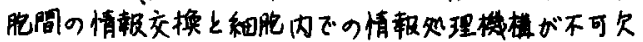

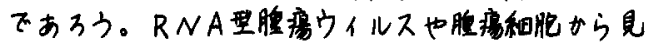
いだされた筧癌遗伝子は何水も知胞の正常遗伝子小 由来し、本来は、稩胞の情報伝道下関与することが 明放にされつつある。このような遗伝子の多くは、 造化上よく保存さ兆ており、遗伝学・分子生物学な ビの良く笔迲したキイロショウジョウバエにも大部 分が見いだされる。同程では、遗伝子機能を分子。 和脆・㑑体の各レベルで研究できるので、情极伝速 の基本原理を理降する上で倛北たモデル如物と考え ることができる。

rafは、Ser/Thr キナーゼをコードし、細㿁 化におウるキナーゼ活性の閶与が示惨されるが、号 の本来の機能は未知である。比cーraf-1をプロ ーブをして、ショウジョウバエの相同遗伝子を单離 し、号の塩基配列から上卜 raf と柾めて数似した タンパク珫の一次柾造を明らかにした。また、この

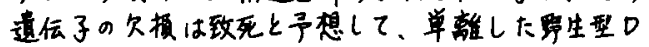

NA断片をPエレメント・ベクターを用いて前入し、 致死形筫の回復によ，て、多数の劣性致死突然变異

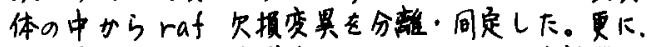

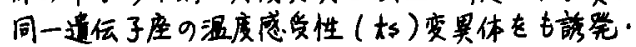
分望した。吕して、三北らの突然变具体を用いた主 に㑑体レベルでの研究から「的は、稩胞增殖の制御

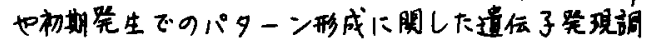
䬦などに阅与する多楼能遗伝子であることを明らか にした。

$1 C 0945$

希少 A T P 存在下での滑り運動のA D P, P i 依存性

安永卓生佐怕善義子

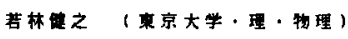

海り遇助には、A T Pのエネルギーの霍战が不可久であると思

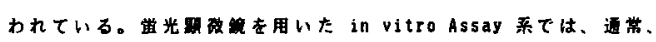

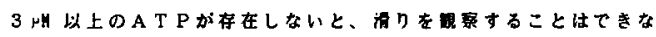

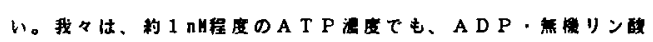

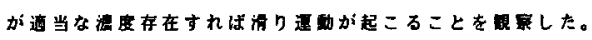

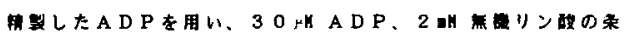
件でも消与かに助くことが既されたか、この時のADPに湿入 しているATPは、1 8 县以てあった。このADPを更にへキ ソカイネースを用いてATPを相的に取り除いたところこの

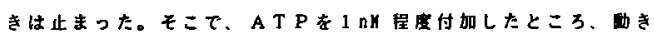

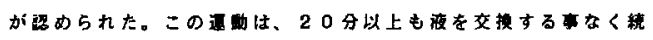
いた。海りの向きは、1 mMOATPのみ存するときの向きに

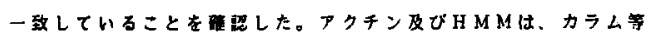

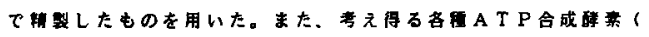

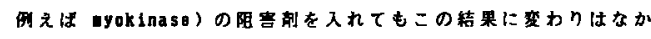
つた。

これらのことは、ミオシンのA T P 结合定数が pHのォーター であるとを考えれば当り前の事であるかか㚘れない。しかし、

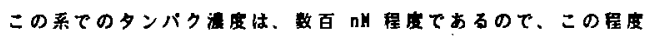
のATP（タンバク算( H M M ) モル比て數百分の一）て此いて

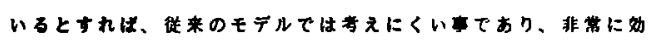

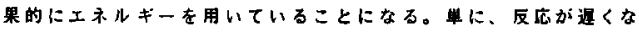
つているからというたけでは船粉でないのてはないたろうか。

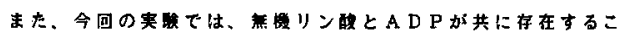
とが不可久てある。このことから、两者がATPの持つ2面性（ 叹精とリラックス)を果たしていると考えられる。十分なA T P

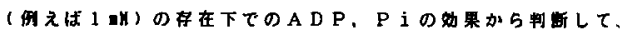
リン酸はリラックスを引き起こし、ADPは力を塔大させる奻果 を持っていると思かれる。。そこで、リン蠤がかと清りが阻害 され物けす、A D Pがないと力の生成が阻害され撸けないのでは ないかという仮説もたてることができる。

化等反店と力学的な作用との肉保については、今まてにもいろ

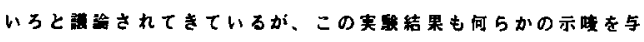
えるであるう。 


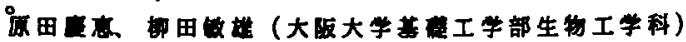

首回、1 A T Pサイクルあたりのアクチンフィラ メントの清走医（D）を、それに同時に相互作用 でるミオシン职部の数が数国に踥隄される短いフ イラメント (约 $40 \mathrm{~nm}$ ) のミオシンコートガラス

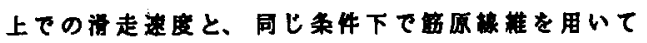
玨定したATPase rateから求めた。もして、Dが 告負荷時には $100 \mathrm{~nm}$ 以上になることを報告した。

今回、再檑成した㖆いフィラメントとアクチンフ イラメントが、実佱ミオシンコートガラス表面上を

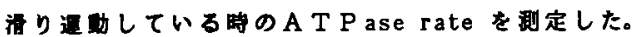
Piとガラス表面上のミオシンの量は、各ヶ高承 のマラカイトグリーン法およひBCA色菜法により 定豆した。海走中のATPase rate はアクチンが存 在する時としない時の若から求めた。 $40 \mathrm{~nm}$ クのATPase rate は网フィラメントとも約 $50 \mathrm{~A}$ $\mathrm{TP} / \mathrm{s}\left(23^{\circ} \mathrm{C}\right)$ C、海走速度は各々 7.2 と 5 . $0 \mu \mathrm{m} / \mathrm{s}$ てあった。A T P ase rateは、相互作用

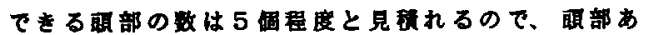

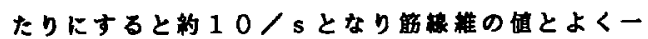

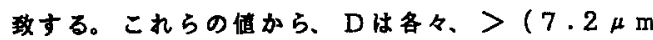
$/ \mathrm{s}) /(50 \mathrm{ATP} / \mathrm{s})=140 \mathrm{~nm} / \mathrm{ATP}$.
$>(5.0 \mu \mathrm{m} / \mathrm{s}) /-(50 \mathrm{ATP} / \mathrm{s})=100$ $\mathrm{n} \mathrm{m} / \mathrm{AT} \mathrm{T}$ と求まつた。

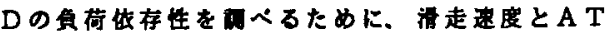
Paserateを低涯度のA T P 存在下て测定した。低

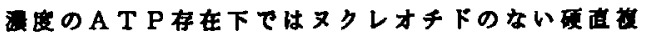
合体が形成され、それが活性化されたクロスブリッ ジによる梢りカに对しての抵抗になることが期特さ れる。

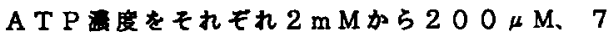

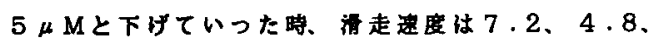
$2.6 \mu \mathrm{m} / \mathrm{s} に な り 、$ 最小フィラメント長あたりの A T P ase rateは $50 、 53 、 55 / \mathrm{s}$ でDは各々 $140 、 90 、 46 \mathrm{n} \mathrm{m}$ 以上と求まつた。この落果 は、Dの大をな值が無頜荷来件下に特有のものでは ないことを示している。

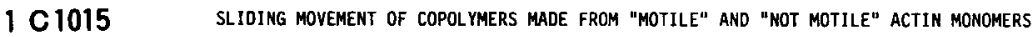
Ewa Prochniewicz-Nakayama, Toshio Yanagida

Hotani Project ERATO, and Department of Biophysical Engineering, Faculty of Engineering Sciences

Osaka University

In the present series of experiments we try to get some insight into the molecular mechanism of sliding of actin on myosin heads fixed on a glass surface by examination of movement of copolymers made from chemically modified "not motile" monomers and unmodified "motile" monomers. Ul timate goal is to know how many "motile" monomers must interact with myosin to set filament in motion and how many nonmotile monomers within the filament can inhibit its sliding. Act in monomers were crosslinked by glutaraldehyde or EDC; in some cases before crosslinking the monomers were fluorescently labeled with IAR. Both kinds of crosslinked monomers could be reversibly polymerized, but the rate of depolymerization depended on the kind of modification: polymerized. EDC-monomers depolymerized much more slowly than polymerized glutaraldehyde monomers. Both kinds of crosslinked monomers copolymerized well with unmodified actin.

Polymerized glutaraldehyde monomer and EOC monomer did not slide on HW fixed on a glass surface. Inhibition of movement was not due to some $k$ ind of irreversible attachment, since the modified actins could be removed from hmos coated surface by addition of large amounts of unmodified motile actin, but was rather due to some alterations of actin properties. Copolymers were prepared from unmodified motile actin and crossinked actin monomers which were fluorescently labeled by IAR. This enabled us to confirm directly copolymerization as well as determination of the amount of crosslinked actin in the copolymers. With decreasing amount of crosslinked monomers in the copolymers the amount of sliding filaments
and the rate of sliding increased, and when the amount of crosslinked monomers in the copolymers was less than $20 \%$. almost all filaments slided and their speed was similar to the speed of control actin. This result was independend of the kind of crosslinked monomer incorporated in the copolymer - EDC or giutaraldehyde modified - although polymerized - EDC or glutaraldehyde modified - al though polymerized
crosslinked monomers differed in their interaction with $\mathrm{Hry}$ in the presenc of ATP. Affinity of polymerized actin to Hin

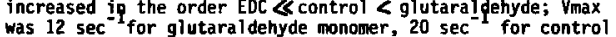

monomers and almost no activation of HMM ATPase by polymerized EDC monomers was found.

The obtained data indicate that driving force for sliding The obtained data indicate that driving force for sliding is generated by interaction of myosin with a few, 2 or 3 , monomers and also suggest that during sliding myosin filament.

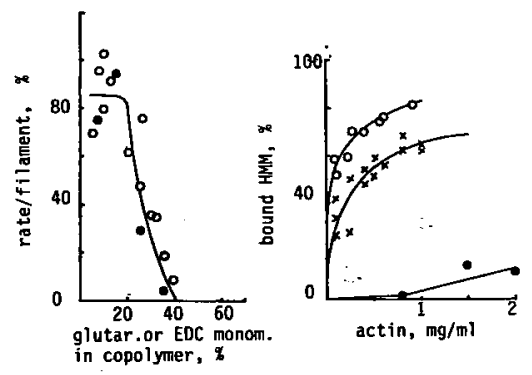

- glutaraldehyde monomer

- EDC monomer

$\times$ control monomer 


\section{滑り運動中の F アクチンの虽光偏光顕微鏡による観察}

中山治人゚、中山エバ（新技団・宝谷ブロジェクト）、柳田敏雄（阪大·基硞工）

アクチンとミオシンの滑り通動において、1本のF クチンを钼察し、その中のアクチンモノマーのふるま いをミリ秒の分解能で解析することを目的として、光 学顕微鏡を改良し、測定を行なった。

フクチンはローダシシより桇色し、スライドグラ スに固定したミオシシ上を滑らせる。アクチンを蛍光 影微鏡によって可梘化し、その蛍光の偏光成分を定最 测定することにより、蛍光分子のフィラメント軸に対 する角度を決的る。

测定システムはレーザー光源を用いた逶過型偏光蛍 光顕微鏡であって楼成は右図の通りである。

(1) 分子の回転を調べるために倨光を用い、散乱光 はビームスプリッタによって偏光 2 成分を分猅 し、同時に計测した。

(2) 蛍光色素 (口ータミン) からの蛍光を湘定する ので、レーザーからの単色光 $(514 \mathrm{~nm})$ お よびダイクロックミラー、カットフィルタを 用いた。

(3) 1 本の年アクチンの一部のみを测定するために、 レーザー光を試料面で約 3 ミクロン以下に集光

（4）照射光量を必要最小限にするため、および偏光 面を回忶させるために、光スイッチ(ホッケル

测定例を右图 (下) に示す。試料は $\mathrm{r}$ i g o r 条件 下て、フィラメント軸は久射光の㭊光方向と平行であ 万。(a) は入射光に平行な偏光成分、(b) 成分である。光雃色がみられるが、2成分の比が二定 であるので测定には影䪪しない。2成分の比加ら求め たフイラメント䡍と蛍光分子の吸収ベクトルとの角度 は2 $26^{\circ} \pm 2$ 吔た。
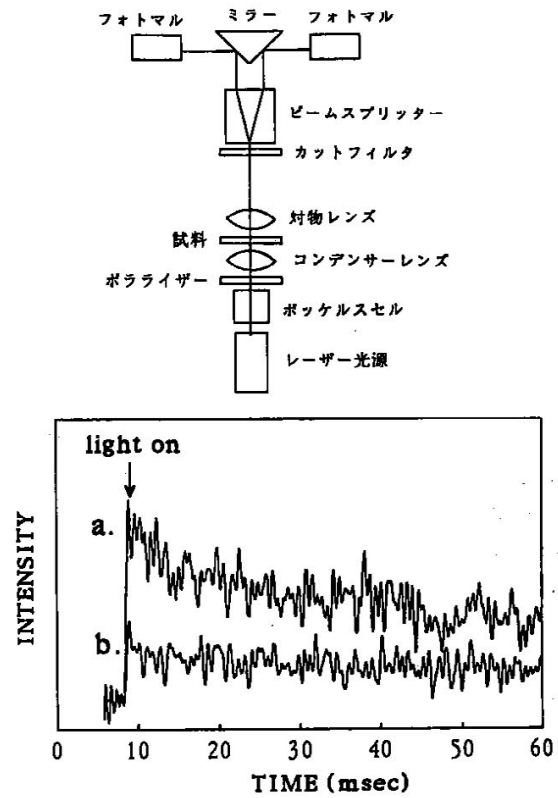

$1 \mathrm{C} 1045$

再榑成系におけるアクチンフィラメントの回転消り罢野

石岛秋彦、田中﨏一郎 (本田技術研究所 - 和光)、石渡信一（早大·理工 ·物理）

再楼成系におけるミオシン上のアクチンフィラメントの消 り運副において、我々はアクチンフィラメントがラセンやル ープの形䚀をとることを银察した。アクチンフィラメントが

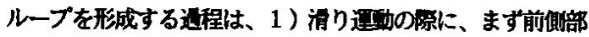

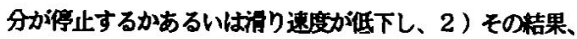
フィラメントの中程にーアービン状のたかみができ、3)そ れがラセン形に変化し (図 1 参腛)、4) 続いて後时部分の 滑り遈䡃に伴ってループか形成される。

このラセンの巻き方を約50例について分析したところ、 右ラセンと左ラセンの此は $1: 1$ とならず、7:3であり、 明らかに右ラセンの功高制度であった。このことは、ア クチンフィラメントがラセンアルーブを形成するのは、槊摇 娌やミオシンとの不均一な結合などのランタムな要因による ものではなく、ミオシンがアクチンフィラメントに対して右 ラセンを形成するようにトルク (㻅りか) を与えていること、 つまりトルクによってフィラメントが回転軍和していること を強く示崚している。次に闍题となるのは、右ラセンと左 ラセンの割合か诂または左の一方のみとならずに7 : 3とな つた理由である。その理由を考える际に、右向きトルクと
左向きトルク (図2 参炤) が7：3の咭合で生じる可能性も あるが、我々は、ATPの消費を伴ってミオシンから受ける トルクの向きは右か左の一方のみである、と仮定する。 現時点で、アクチンフィラメントの回転の向きを直接礁

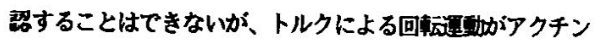
フィラメントの消り方向に対して右向きか左向きかを、上鱾 の仮定と既察結果を基に被合する。

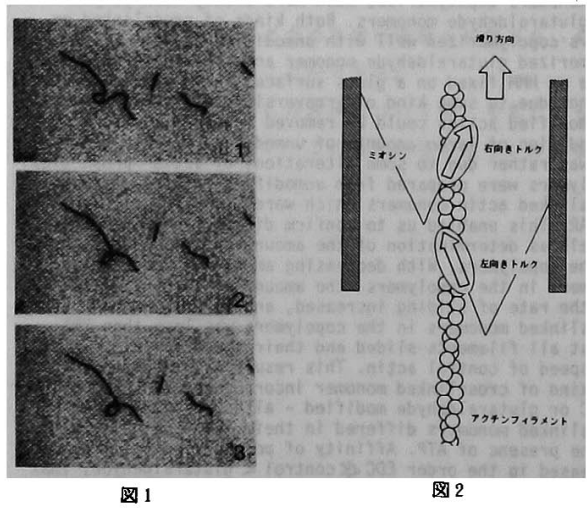




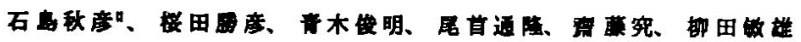
(医大・基臹工・生物工学、本田技研")

我々は一本のアクチンフィラメントをカラスマイ クロニードル用いて端作し、ニードルのたわ 加らアクチンフィラメントに発生する腲カの测定 を行ってきた。今回はこの分子超碳㩲作技衔に、二 ードルの变位をフォトタイオードで即定する技懒を

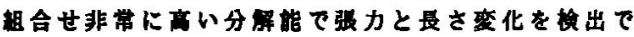

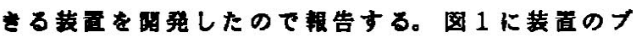
ロックタイアダラムを示す（1C1115の图盟）。こ

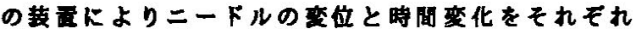
1 オンダストローム、0． $2 \mathrm{~m} \mathrm{~s}$ の分解能で触出で をるようになった。

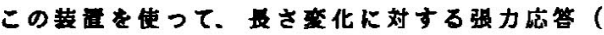

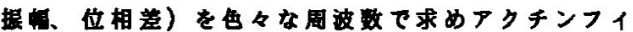
ラメントとクロスフリッジ（ミォシン部士 $\mathrm{S}-2$ ） の的的性事を求めている。これらのパラメーター

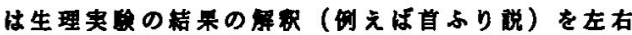
するほと重大なものであるが、これまで直接即定す る手段がなくすへて仮定して解駅してきた。これら の結果を基に、单一アクチンフィラメントを用いた

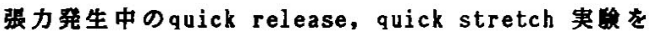

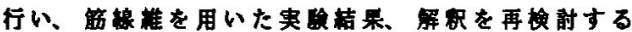

\section{予定である。}

また、これまての実卧ではニードルを用いてきた が、もつと摽作性の良いレーザーを用いた”optica 1 tweezers"（光ピンセット）法による新しい分子操

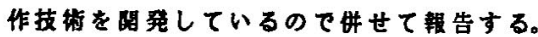

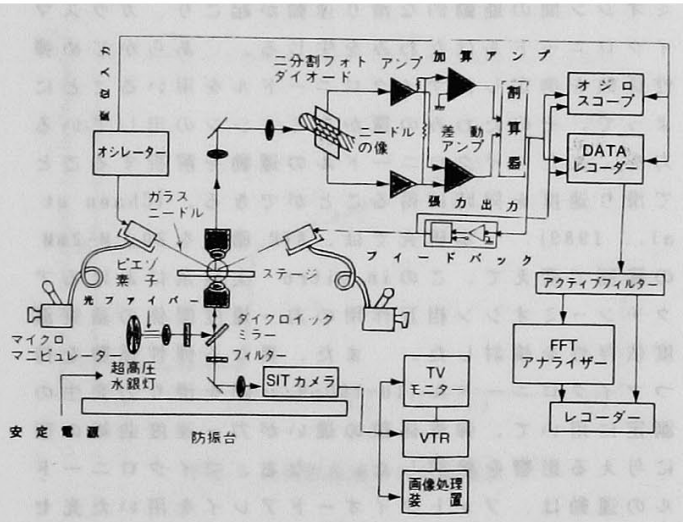

図 1

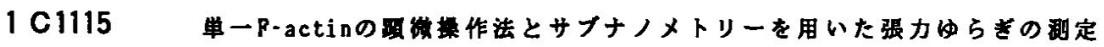

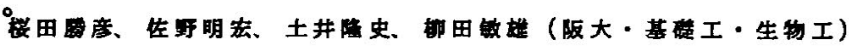

我々は一本のアクチンフィラメントをマイクロニ ートルで捕らえ、フィラメントに発生する張力を非

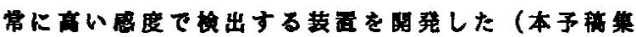
1（１１１１００）。この淔を用いて張力のゆらをを 到定した。图1にあるように、アクチンフィラメン トのー蝡をニートルて捕らえ、もう一蝡をミオシン ユート表面に触れさせ石。発生した㖘力はニードル の変位として埃出される。倨力ゆらきの大きさは、 ミオシン嘼部の数のルートに逆比钢する( $\sqrt{\left\langle\Delta P^{2}\right\rangle}$ $/<\mathrm{F}\rangle \propto 1 / \sqrt{\mathrm{n}})$ ので.今の系のように腲力 発生に加するミオシン䫏部の数加 30 個玨度しか

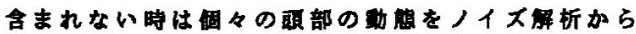

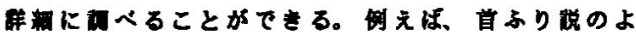
うに一回のA T P 分解反医中に一回の首かりが起こ ると镸カはパルス的に発生することになり、非常に 大をな镸力ゆらをが籍されることになる。图 2 に

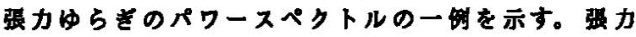
ゆら艺は首ふり䂱で期待されるより数十倍も小さか つた。この小さなゆらきがアクキンフィラメント及

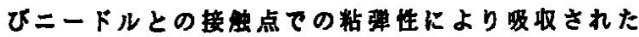

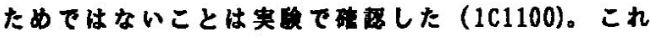

らの結果はミオシンが A T P 分解中の㱠どの珰間后 㴗一定の腲力を発生していることを强く示唆してい る。電演では単的ミオシン、 $S-1$ を用いたとき、 清走中のゆら美についても報告する予定である。

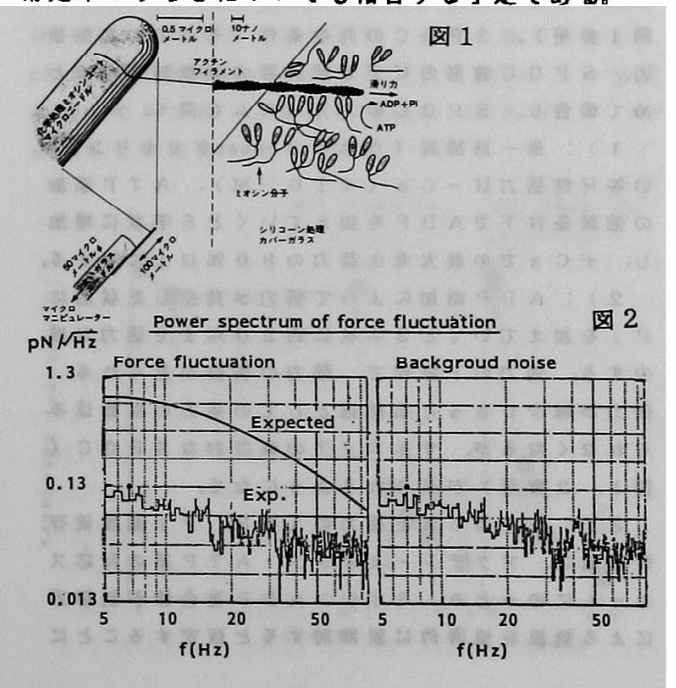


大岩和弘、茶回茂、・新免解男、杉晴夫

(帝京大・医・生理、*東大·理・植物)

車軸蕅節間䎩胞内の葉粶体列の表面に江。アクチン 線䊒の束が極性を揃えて配列している。ウサキ骨 格能より精䌘したミオシンフィラメントを付普させ たカラスマイクロニートルを、このアクチン線維束 (アクチンケーブル)に接触させると、アクチンー ミオシン間の能動的な消り運動が起こり、ガラスマ イクロニードルはたわみを生じる。あらかしめ弾 性係数を溂定したマィクロニートルを用いることに よって、そのたわみの量からミオシンの出している 力を、またマイクロニートルの運動を解析すること で滑り速度を同時に得ることができる。(Chaenet aI. . 1989). 本研究では、ATP湿度を $20 \mu H \sim 2 \mathrm{mH}$

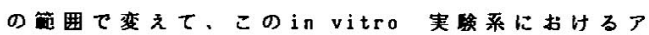
クチンーミオシン相互作用の力一速度関伱の基質漊 度依存性を梌討した。また、異なる挷性係数を持

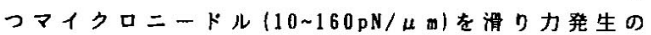
娜定に用いて、弾性係数の連いか力一速度曲線の型 に与える影量を模討した。なお、マィクロニート ルの量動は、つォトタイオートアレイを用いた光セ ンサーで测定した。ママクロニートルの運動速度 纴負荷が徐々に增えるにしたがって減少して滑り力
とマイクロニートルのたわみによろカがっり合った ところで停止した。この過程を解析して得られた 力一速度曲線はauxotonic 策件下で得られる単一筋 線維のそれと同じく上に凸の曲線であり、この曲線 の型はATP惯度によって大きく変化することはな加 つた。一方、比較的小さい弹性係数を持つマイク ロニートルで测定した場合の消り速度は、大きい弾 性係数のマイクロニードルで得られる滑り速度に比 ベて速い檤向が見られた。

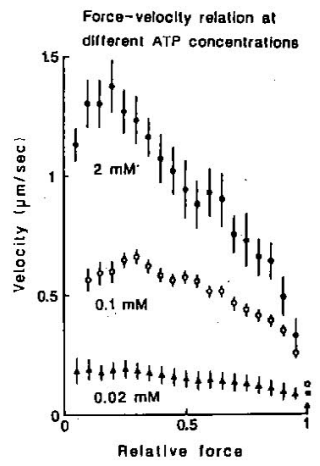

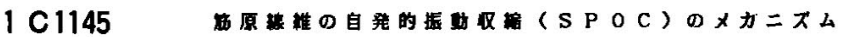

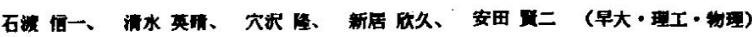

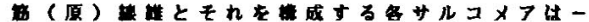

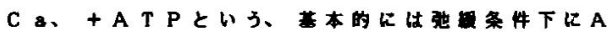

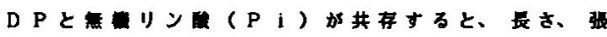

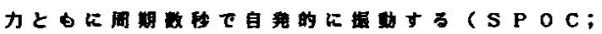

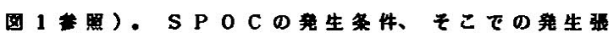

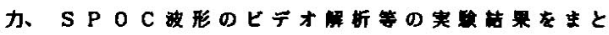
めて告し、SPOCのメカニスムを探る。

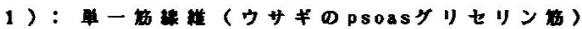

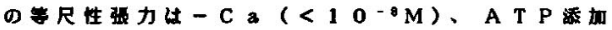

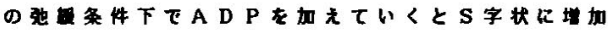

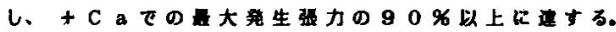

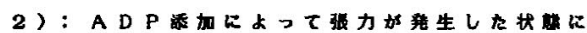
P i 加えていくと

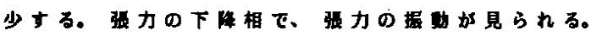

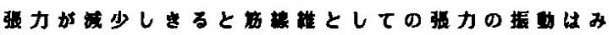

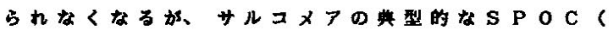
图1、2萧䁌)加見られるようになる。

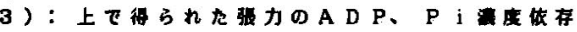

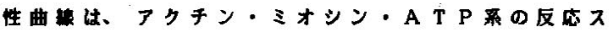
キームにのっとり、ミオシンADP直合体加制系

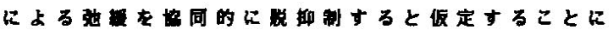

よって定的に再现される。

4)：物原期中ての各サルコメアのSPOC 振

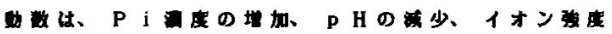
の增加比って地する。

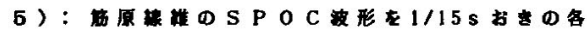

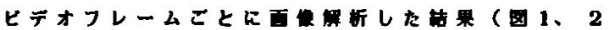

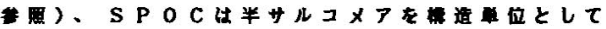

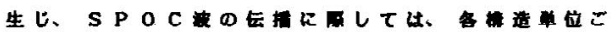
$\varepsilon k$ stretchactivation $\zeta$ release relaxation

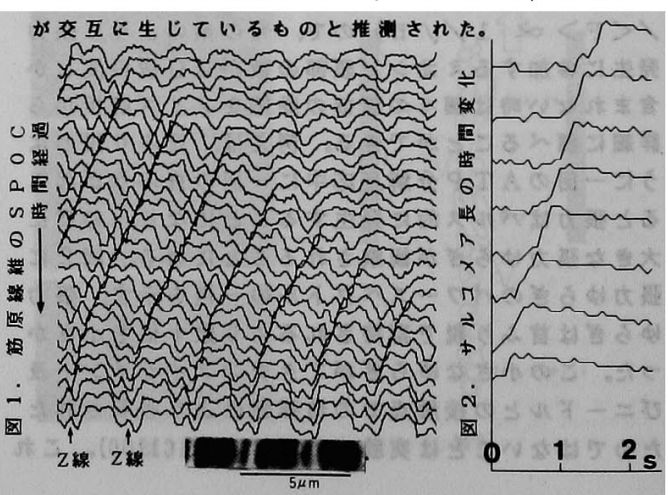


木村和史、本多元、径野一期

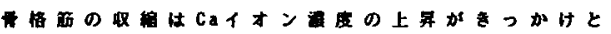
るって起こる。これはAIPase呫住の上年として如ら

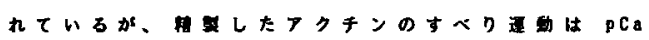

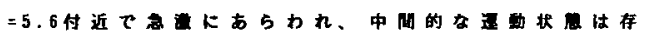
在しないことが跟告されている(1)。本确究ては、

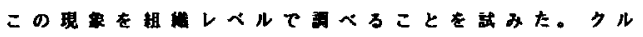

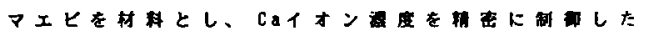

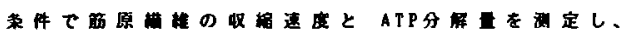

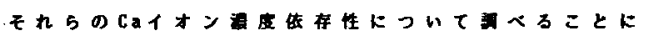
した。

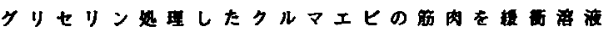
中で杔シナイスし、リラックス液に流する。こ

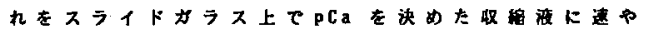

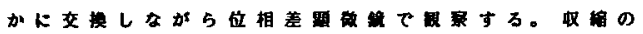

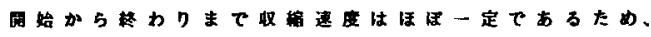

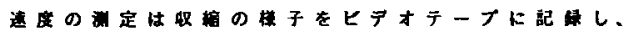
それをコンヒュータ面面上にトレースすることによ

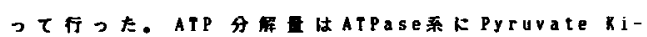
nase 系と lactic dehydrogenase系を同时に共役さ せ、NADHの娍少を遍路することで洒定した。

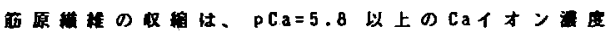

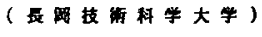

て起こり、妌ししたグンの合と同しく中间的

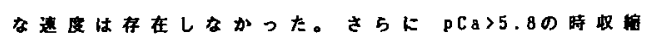

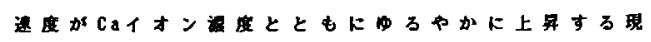

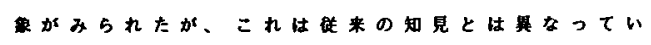
た。

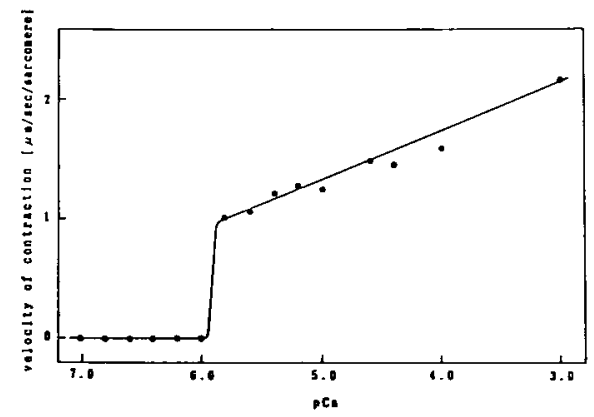

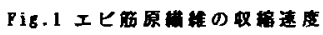

(1) 多. H. Mol. Biol. (1989)

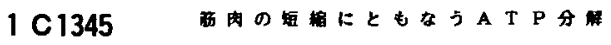

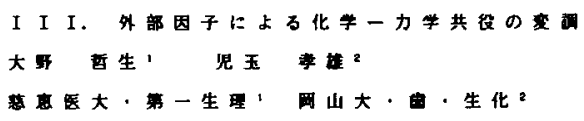

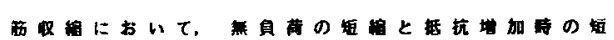

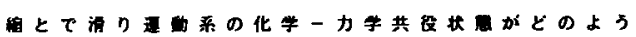

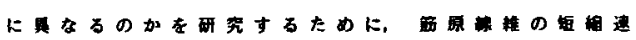

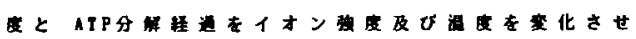
て率した。

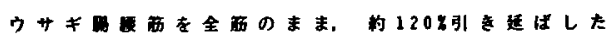

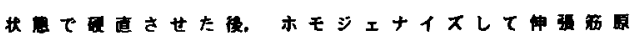

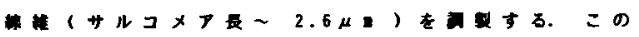

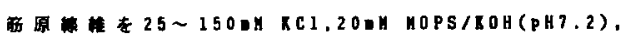

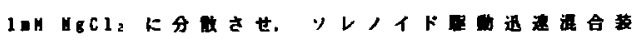

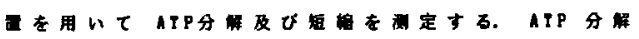

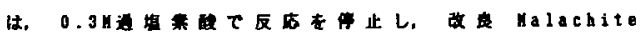

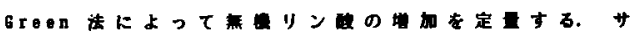

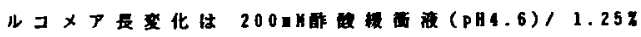

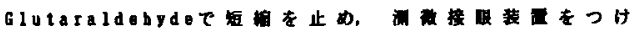

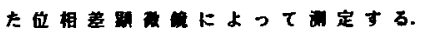

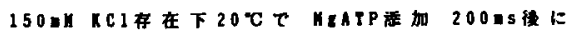

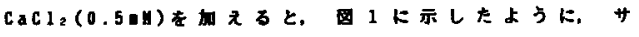

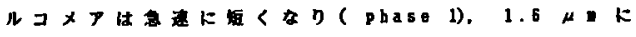

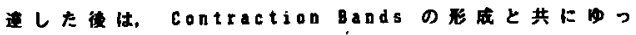

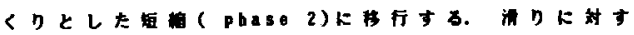

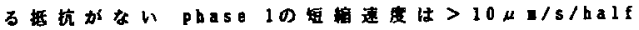
sarcosereであった. このとを ATPOPIoduct Releseはほとんと見られない.これに就しりに

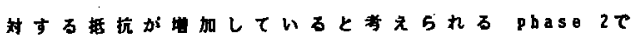

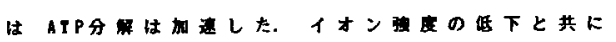

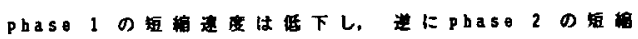

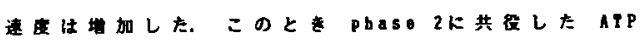

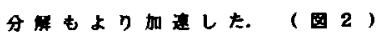

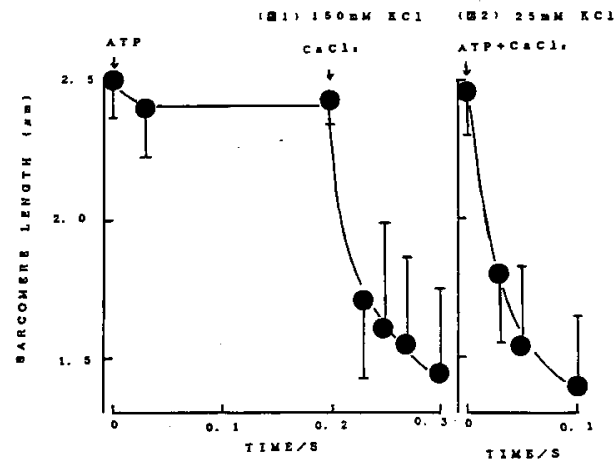




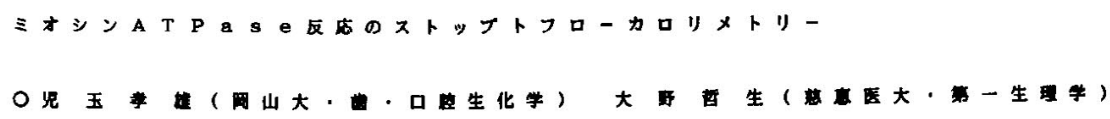

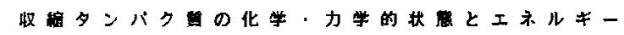

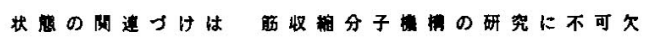
でありカロリメトリはこのための主要な船析法て

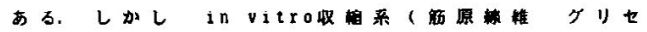

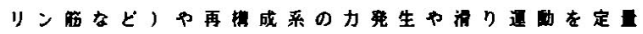
的上㣜定できる来件下ての力ロリメトリをおこなう にはこれまてにも堷して高点寿の助力学的解

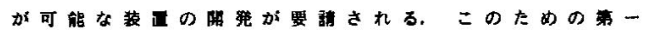
步としてわれわれの開䈳したストッブトフロ一カ ロリメータについて

(1) 新しいせンサの网笔

(2) 桓进坏境の改良

（3）园定の自化

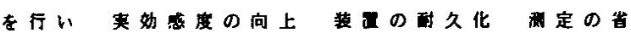
力化をはかっている。

【センサ】ジコニアセラミックスの基都に

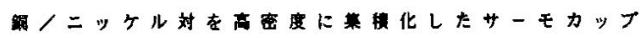

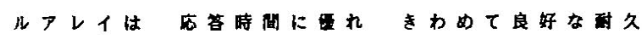

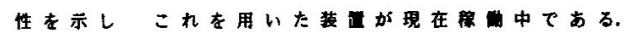

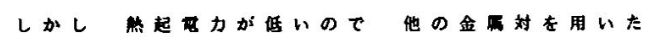
新しいサーモカッフルアレイを現在霜筧中である。

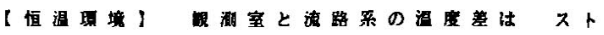
ッフトフローカロリメータの実奻感度を支远する主 要因のひとつてある. 合回この泪度差を小にす

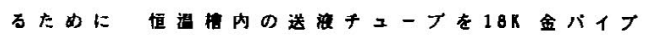

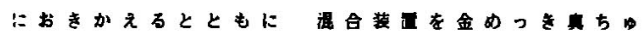
うにした.

下图壮この装亘の性能テストの一牫として行っ た ミオシンサフフラブメントー1とA T P の相互

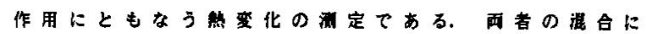

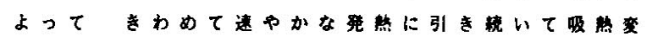
化のあることが明かでる. 前者仙和的中に完了す

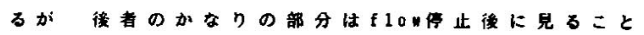
かでる.このように结合したATPの加水分师

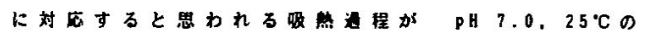

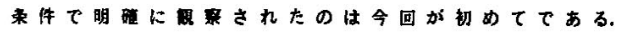

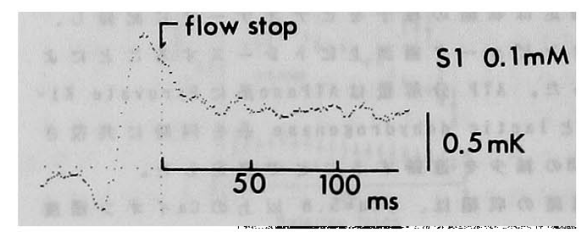

1 C1415 骨格筇筋原線維の等尺性張力とATPase活性の同時测定

○吳林なご、小川靖男（順天堂大・医・薬理）

横紋筇筋原線維の張力発生とATP加水分解速度と の対応関係について検討するため、我々はモルモッ ト骨格筋のskinned fiberを用いて両者の同時测定 を行ってきた。ATPase测定は、落射型蛍光顕微鏡を 用い、生成したADPを醉荸カップリング法により NADHの減少として観测し、一方、張カトランスデニ ーサーにより等尺性張力を同時に測定した。ATPase 活性を今迄は相対值で表わしていたが、今回その絶 対值を評価することを試みた。

まず、使用する標本において、筋小胞体の寄与が どの程度であるかを明確にするため、森本・大概の 方法により、mechanically skinned fiberからトロ ボニンCを完全に除去した標本で湘定した。おらか じめdetergent (CHAPS $1 \%$ ，15分) 処理した標本 では、張力の消失とともにATPase活性の消失が見ら れ、トロボニンCを再添加すると、両者共回復した。 一方、detergent処理をしないトロポニンC除去標 本では張力が発生しないにもかかからずATPase活性 が認められた。以上の結果から、skinned fiberの 膜成分（主に筋小胞体）のATPase活性は、mechanically skinned fiberを1\% CHAPS，15分処理する
ことにより完全に除去できることがわかった。この 筋小胞体のATPase活性は、mechanically skinned fiberでは全ATPase活性の数\%程度であるが、トロ ボニンC除去操作によりもしろ增加した。以降の実 験はmechanically skinned fiberを $1 \sim 2 \%$ CHAPS 処理したものを用いて行うことにした。

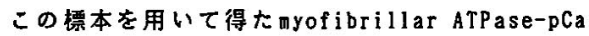
曲線は、張力一 $\mathrm{pCa}$ 曲線よりる低灌度 $\mathrm{Ca}^{2}+$ 領域にあ った。ATPase测定のための蛍光测光面積とfiberの 直径から、 $\mathrm{Ca}^{2}+$ 依存性ATP分解速度を概算したとこ 3、pCa 4.5ではmyosin headおたり約 $2 \mathrm{~s}^{-1}$ (at $22^{\circ} \mathrm{C}$ )という值が得られた。この值は既に報告され ている数值と矛盾していない。 


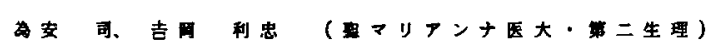

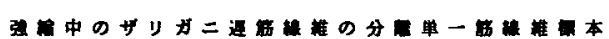

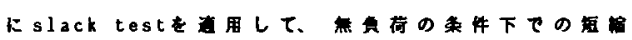

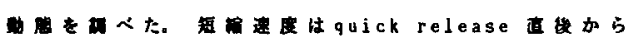

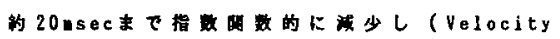
transient). モの定となった. Velocity

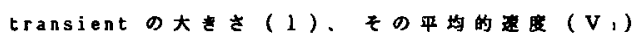

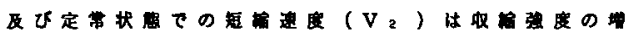

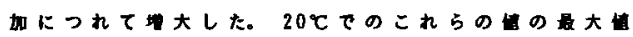
4. $I \sim 450 \mathrm{na} . V_{1} \sim 26 \mu / \mathrm{sec} . V_{2} \sim 11.5$

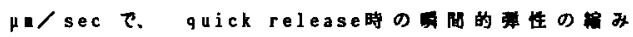

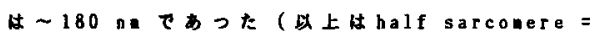

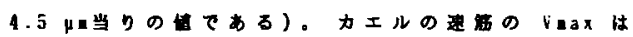
*h $14 \mathrm{\mu a} / \mathrm{half}$ sarcorere/sec" $\left(Q_{1}=2.67 \mathrm{~T}\right.$

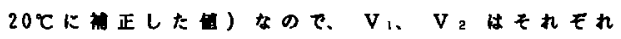

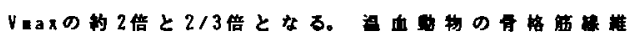

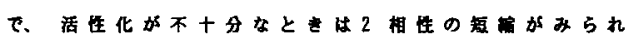

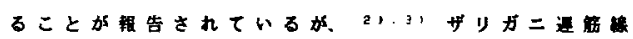

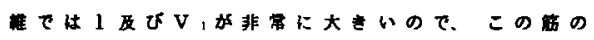
Velocity transient仙りスプリシジのactive cyclingによるものとは思われない。同的稏の 加大当いこと加占、Velocity transientの原因と

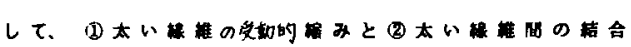

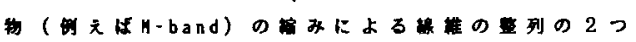
が肃えれる。いすれの合も、 $1=450 \mathrm{na} / \mathrm{half}$

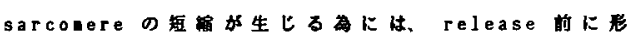
成されていたクロスブリジの大半がVelocity

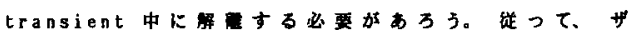

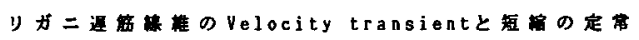

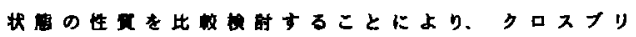

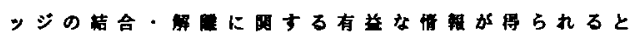
思われる。この目的の元に、Velocity transientと

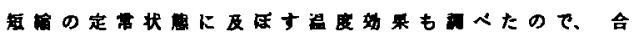
わせて粮する。

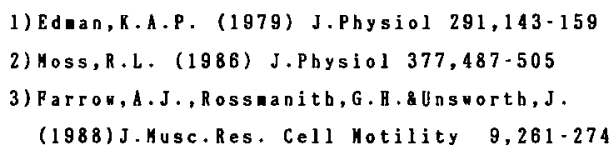

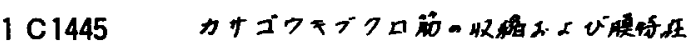

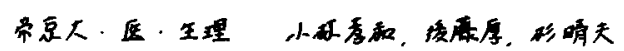

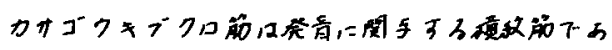

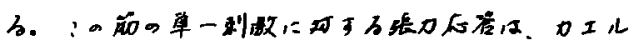

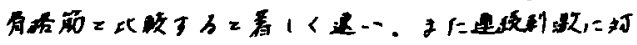

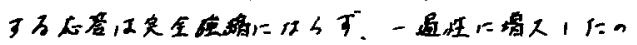

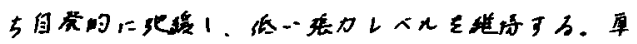

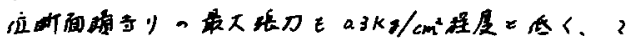

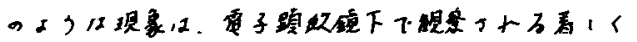

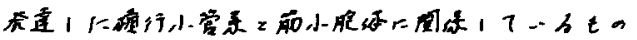

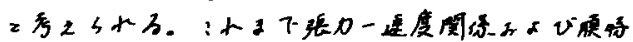

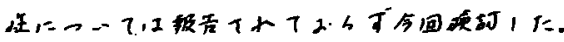

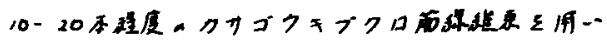

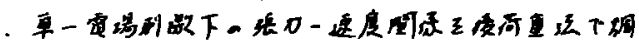

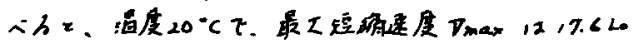

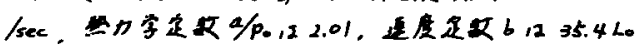

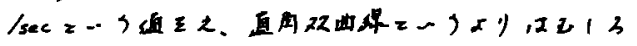

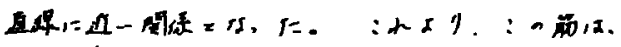

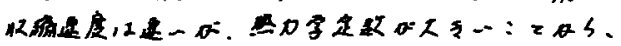

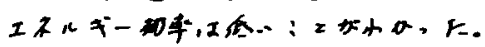

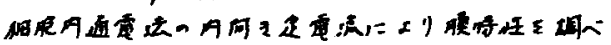

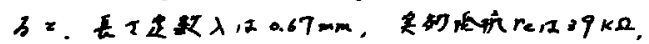

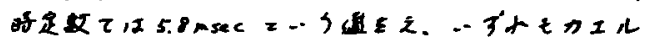

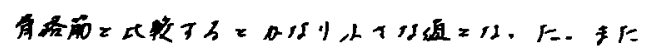

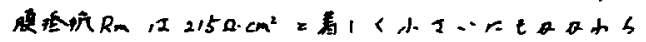

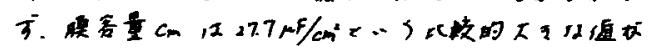

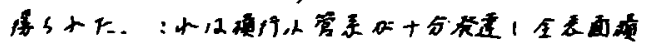

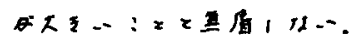

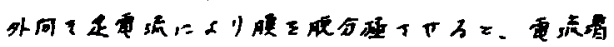

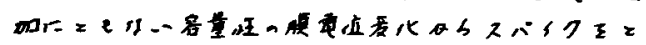

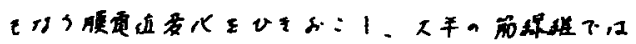

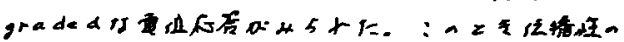

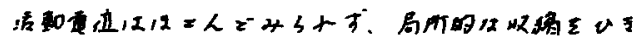

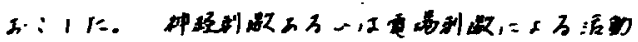

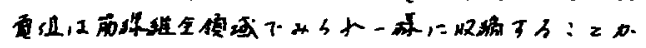

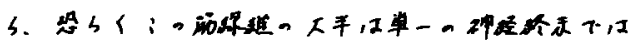

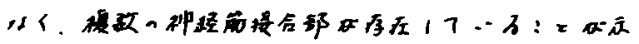

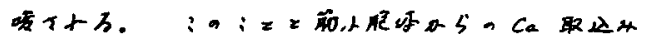

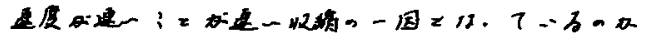

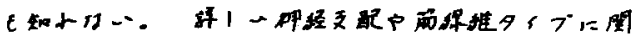

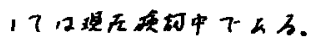




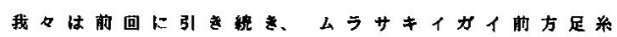

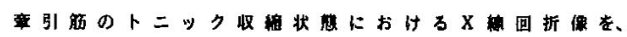

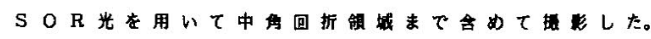

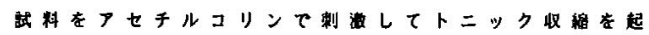

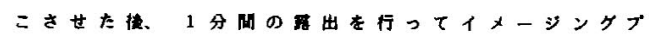
レート上に回折像を眍绿した。

今回は比的高いトニック㖘力が発生したので、

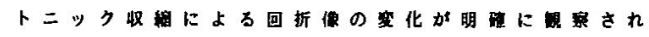

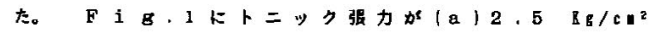

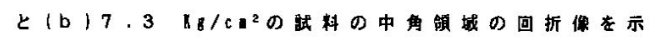

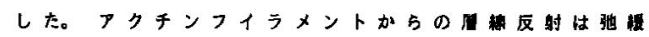

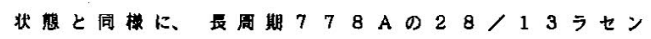
によって指数村出来る。子午上に現れる9，3

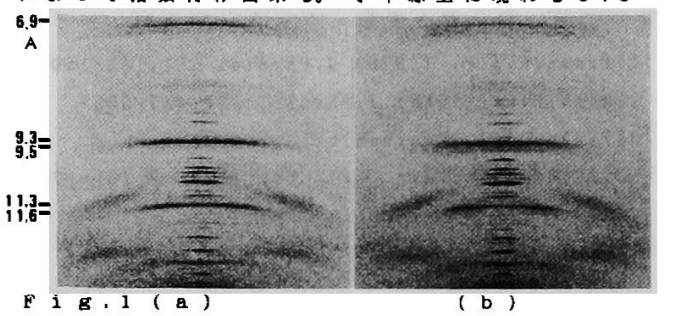

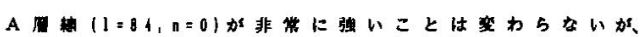

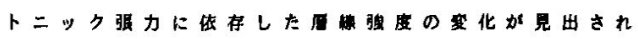
る。アクチンフィラメントがほほ一に消造化し ているとみなされるFi

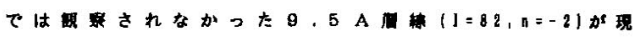

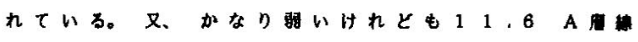
$(1=69, n=-3)$ も見出きれる。これ5法、㖘力の低い

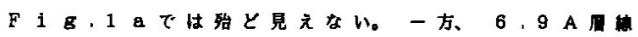
$(1=1 ! 2, n=0)$ は张力の增加に伴い羽くなる。これら

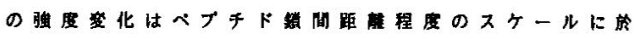

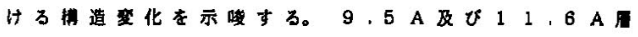

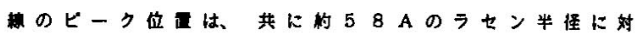

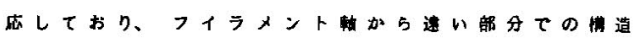
受化加示喛きれる。

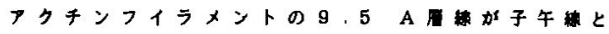

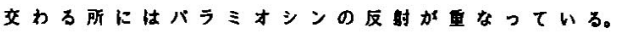

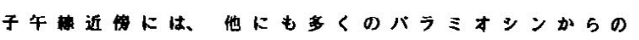

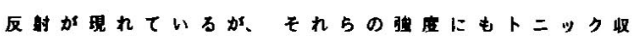
峰に伴う化が見出される。

1) Y, tajia, O. Yoshids, I, Oreda, I, Setat Y. ABelYa, J, APP1, CrYst, 2211989)72,

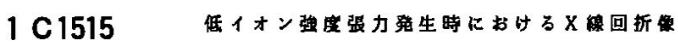

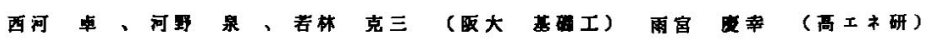

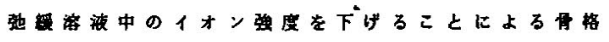
解の植変化の研究は $\mathrm{Ca}^{2}$ の制御を受けはいアクト

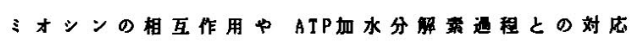

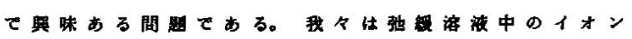

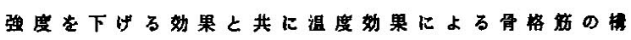

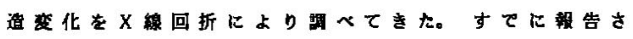
れている結果と一部整する加、サギリセリン

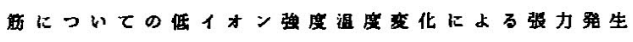
時のX線回折の結果に面きないて路告する。

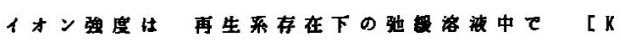

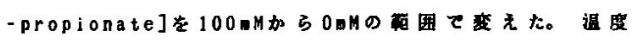

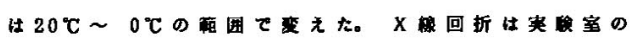
高度発生害とPFの放时光去用いて行った。赤进

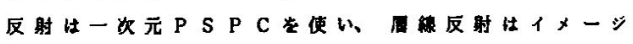
ンタフレートを使って溂定した。

\section{[赤道反射の化]}

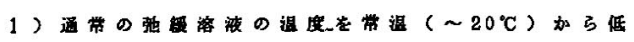

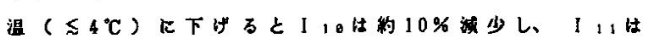

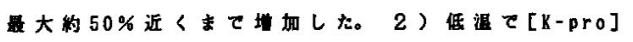

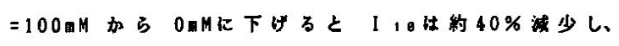
I 11 約 $160 \%$ 增加した。このとき顆著なスティフ*

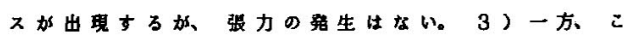
の状態已沮度を节温にするとスティフれス山さらに

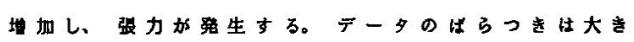

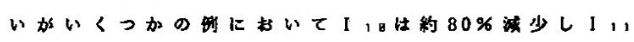

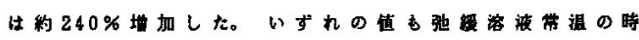

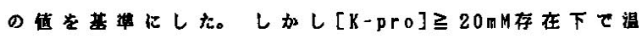

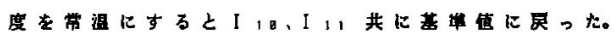
[固镜反射の変化]

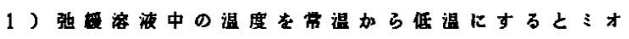

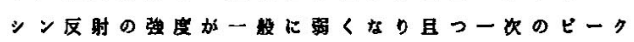
山子午此若干移す了。2

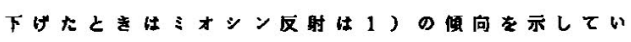

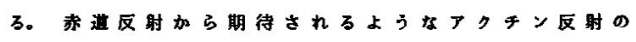

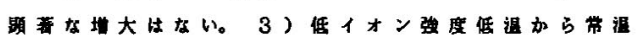

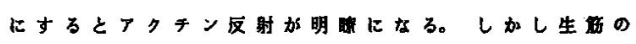

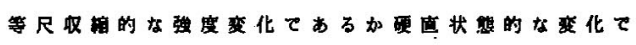

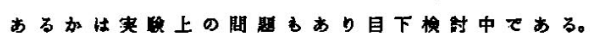

以上の上う結果加らスティフネスや张力变化及

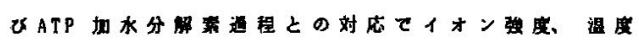
变化によるミオンン嘼部とてクチンの相互作用につ いて知する予定てある。 


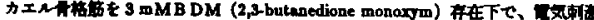

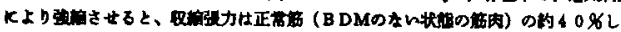

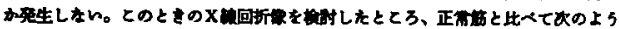

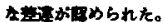

\section{1. 赫段得}

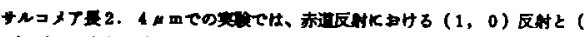

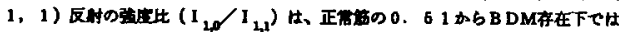

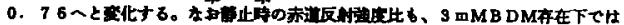
有党化加了。

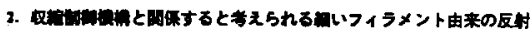

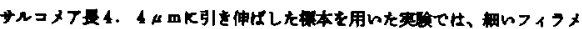

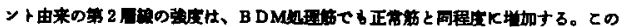

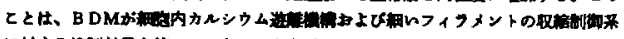

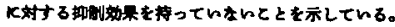

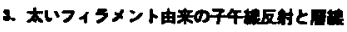

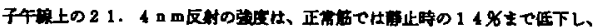

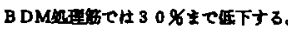

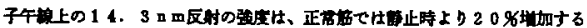

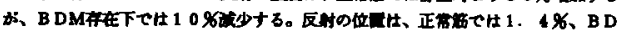

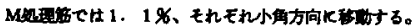

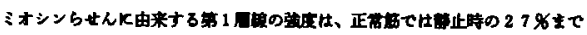

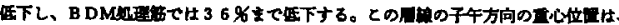

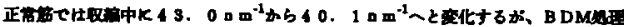

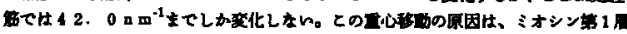

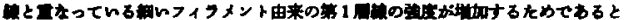

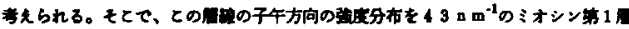

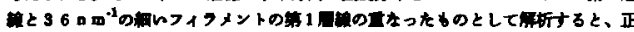

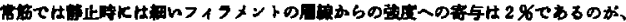

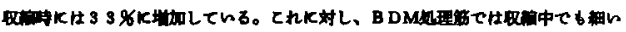

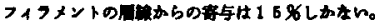

\section{4. 田いフィラメント由来の区射}

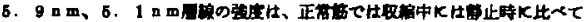

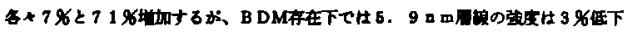

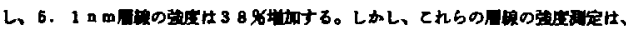

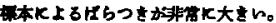

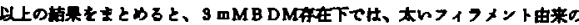

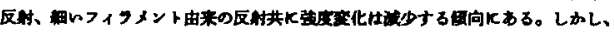

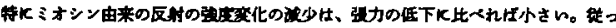

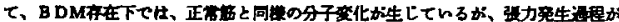

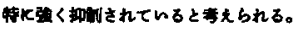

\section{*⿻一𠃋十}

1. Horiuti et al, J. Mucle Res. Cell Motil. 156-104 (1988)

2. Higuchi, H \& S.Takemosi J. Biochem. 105 638-043 (1989)

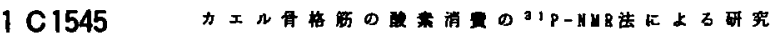

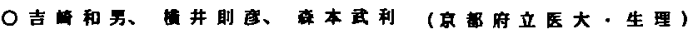

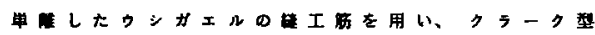

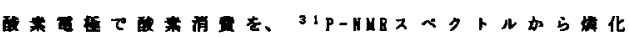

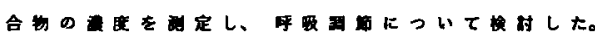

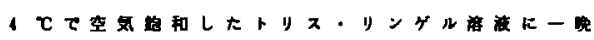

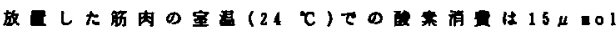

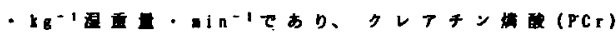

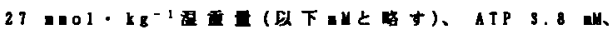

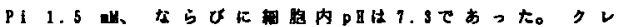

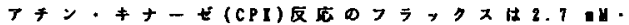

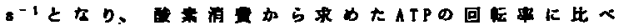

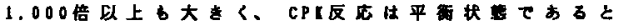

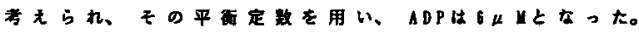

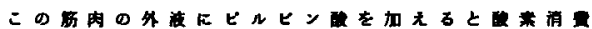

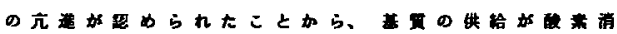

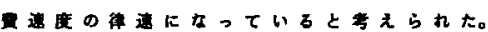

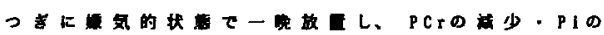

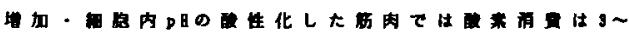

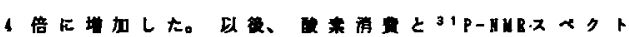

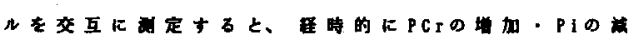

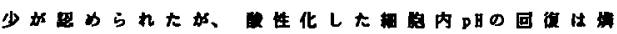

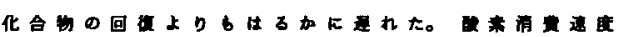

はPCrの堵加と其に量くなった(图 1)。

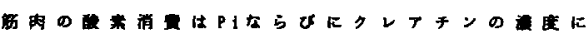

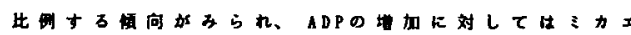
リス・メンテン整に增大した。一方、AD去らひに

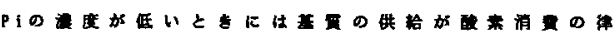
遭因子とるっていることが示骎された。

A)
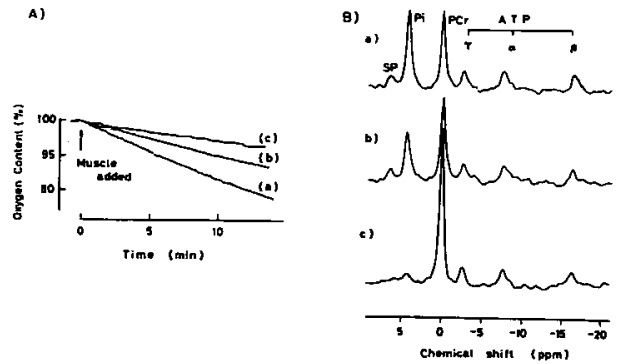

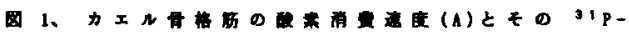

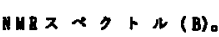


○山田 武範、杉 晴夫（帝京大・医学部 - 生理）

昨年の生物物理学会年会において、 ${ }^{1} \mathrm{H}-\mathrm{N} M \mathrm{R}$ 法 を使って、骨格筋細胞内にある水が構造を取ってい ること及びその水の構造が筋肉の生理的条件によっ て変化することを報告した。今回、この骨格笳細胞 内の水の構造が筇線維の方向に対してある一定の配 向をしていることが分かったので報告します。

ウシガェルの半腱㥞筋を用い、これを裂いて径約

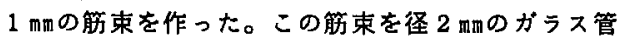
(ロック用の重水が封入してある)に、筋線維の方 向がガラス管の軸に対して一定の角度になるように 巻き付けて、その両端を糸でしばってガラス管に固 定した。この施束をN M R 用のガラス管（径 $5 \mathrm{~mm}$ ) にいれてNMR 湘定をした。こうすることによって 筋線維の方向をNMRの静磁場に対して色々の角度 をすたすようにすることが出来る。NMRの測定は、 J E O L GX-400 核磁気共鳴装置を用いて公温下プ ロトンの共鳴周波数 $400 \mathrm{MHz}$ で行った。また、 水プロトンのスビンの緩和過程は、昨年の年会で報 告したのと同じ方法によって測定した。

筋細胞内の水プロトンのN M R スベトルの1/2幅 は、筋線維を N M R 静磁場に対して平行にした時に
は、約 $25 \mathrm{~Hz}$ あった。ところが、筋線維の方向を N M R 静磁場に対してほとんど垂直になるようにし た時には、これが約 70 Hzに広がった。一方、筋線 維がNMR静磁場に対して平行の場合と垂直の場合 について、細胞内の水ブロトンのスビンの緩和過程 を調べた所、両者の綬和速度は同じであった。以上 の結果は、筋細胞内の水プロトンが筋線維に対して 方向性を持って配向した粠造を取っていて、NMR 静磁場との相対的な角度が变わると、このブロトン のスビン間の相互作用によるNMRスペクトルの分 裂の大きさが変わることを示している。

細胞内にはタンパク質に結合した水に似た構造を らつ水がある。この水棈造が磁場に対して取る角度 によって、水プロトンのNMRスペクトルの分裂の 大きさが、どのように变わるが計算で求めた。一 方、筇線維をN M R 静磁場に対して色々と方向を変 えて、筋細胞内の水プロトンのスペクトルの1/2幅が どのように変わるかを赛験的に調べた。その結果、 筋線維の軸方向に対して約70.の角度で配向したタン パク筫結合水があることが示唆された。

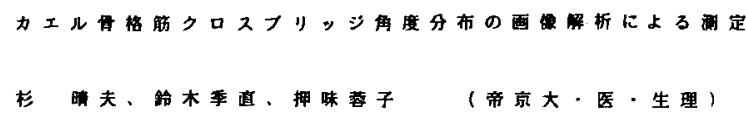

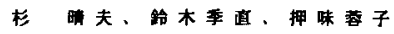

(帝京大・医・生理)

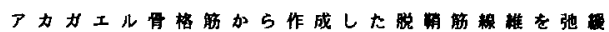

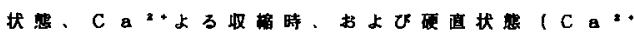

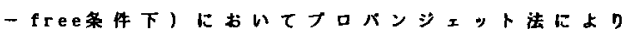

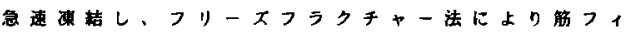
ラメント周のクロスフリッジ(方法上、みかけのも

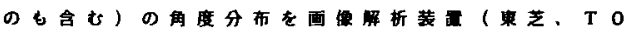

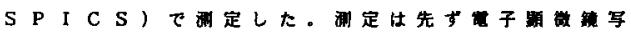

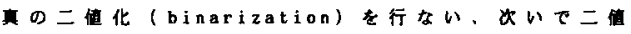
化画を梱 (thinine) し、クロスフリッジの

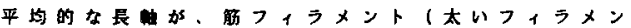

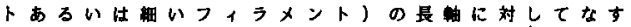

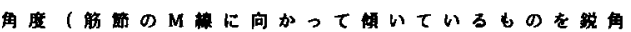

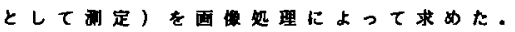

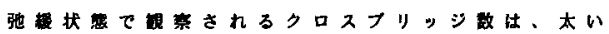

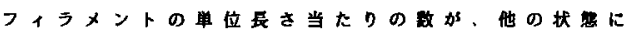

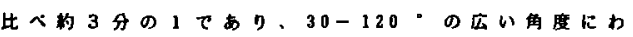

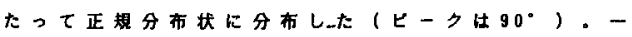

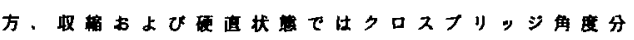

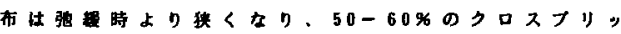

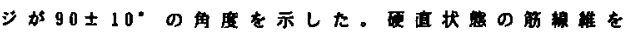
2 - 5\%stretchL、直張力を50-100\%增加さ

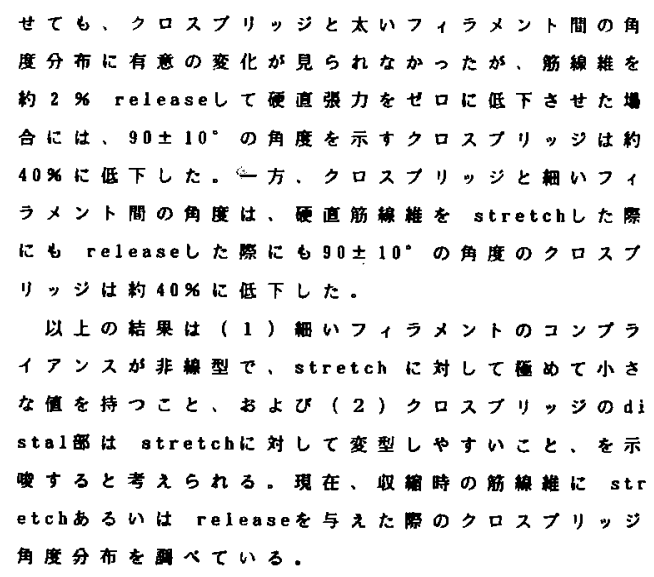




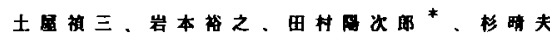

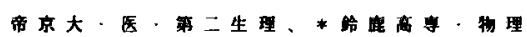

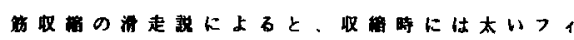
ラメントから出ているクロスフリッジ加フチンと

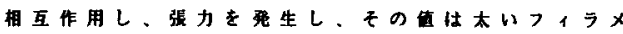

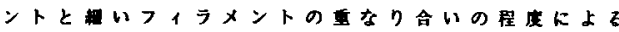
とされる。してクロスフリッジのランフライアン

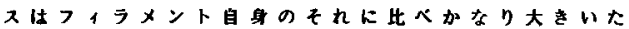

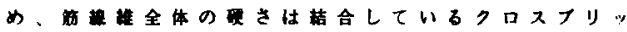

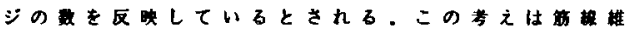

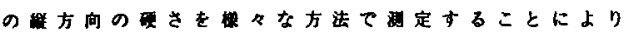

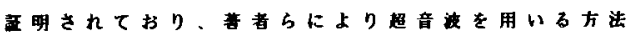

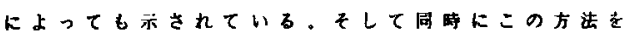

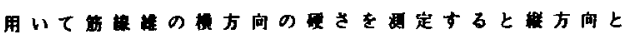

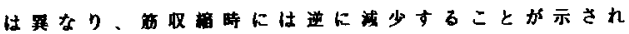

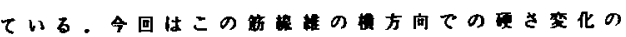

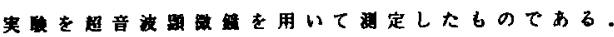

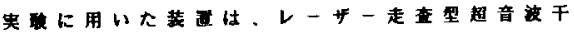
- (scanning laser acoustic oicroscode.

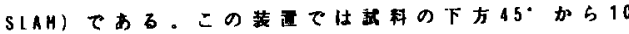

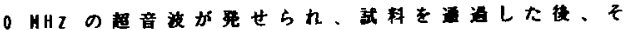
の上新のアクリル野力バースリッフに连する。この

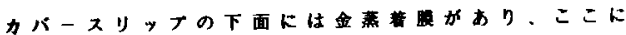

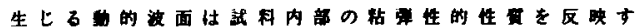

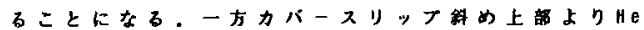

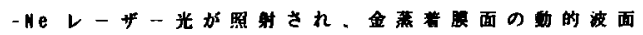

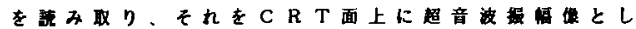

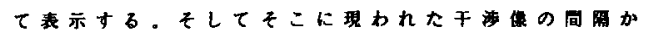

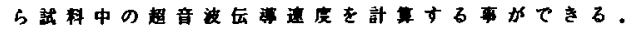

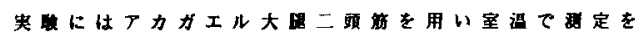

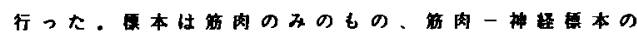

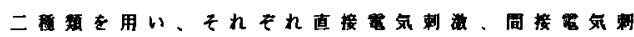

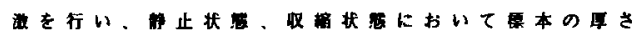

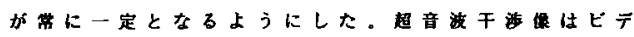
オに記はし、コンビューターにより二直化、湘化

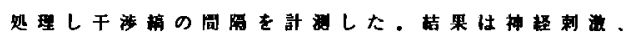

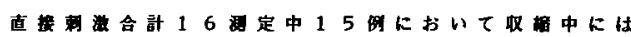

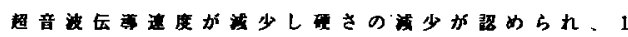

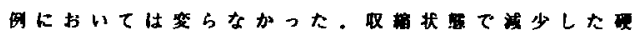

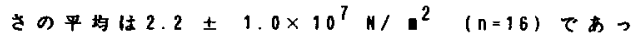
た.

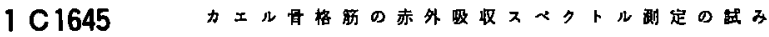

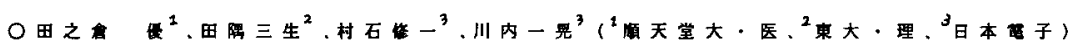

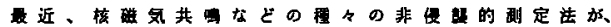

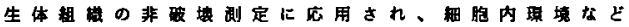

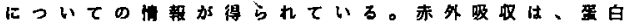

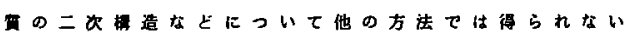

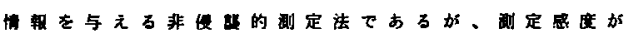

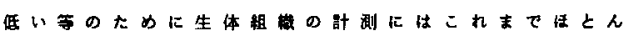
と直用されていなかった。とろか、近年フーリエ

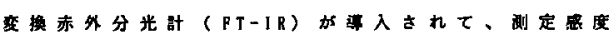
が向上さるととしに即定時閂が著しく短曾された。

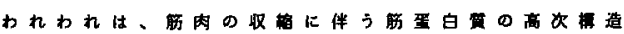

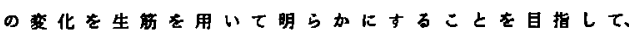

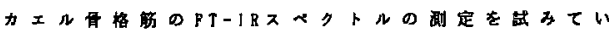
ろ。モの精果、これまてに反时( ATR) ステクトル を剧定することにより、生理的策件下での筇肉の赤

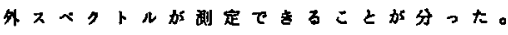

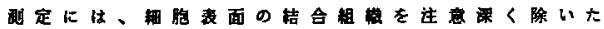

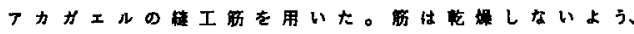

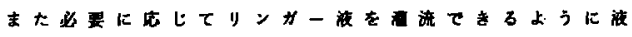
体也几内に保持し、ZnSeフリリスム

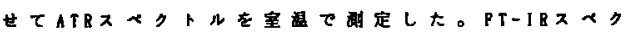

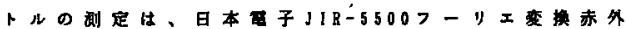

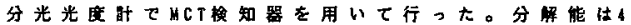

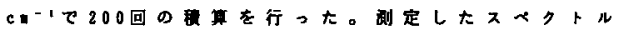

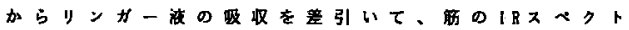
儿を得た。

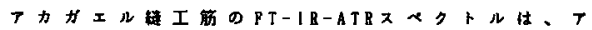

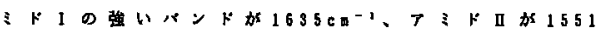

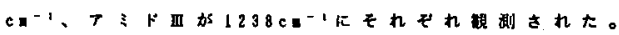

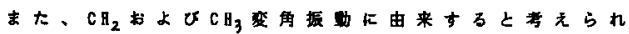
бひント

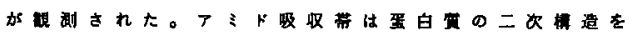

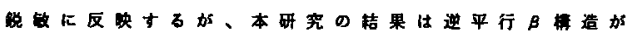
多いことを示している。得られたスへクトルか钿胞

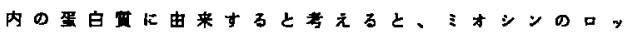

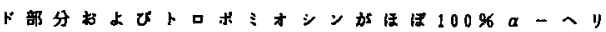
ククをとつていること加知斿ているのて、をれ

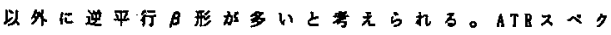

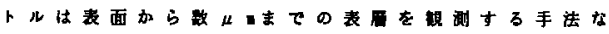

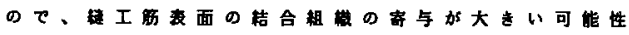

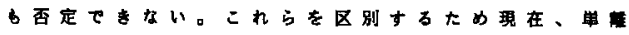

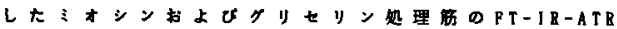

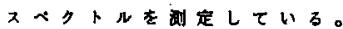



研究

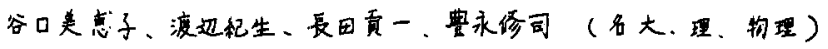

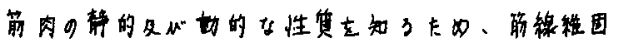
有学光( intrinsic f l u o r e sc

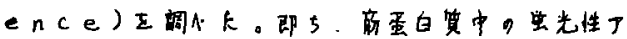
ミノ酸我基(フェニルアラニン、ナロシン、トリプ

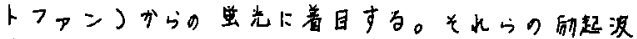

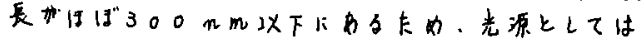
短波炎領城において大強度分布を ト口之枚射光( SOR光)を用いた。二の光源は。 他
○、单調なスペクトルをもつ、

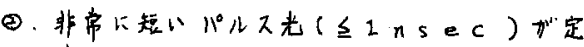 常的に近いが去古で得られる。

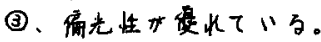
(日)、指向性加良い。

といつ利点加ちる。

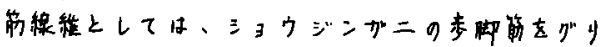

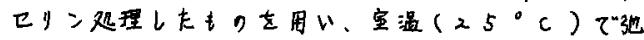

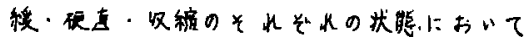

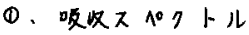

(2)、而起スペクト儿

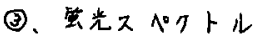

(4)、出光寿命

女测定した。特に中单一光子计数法により测定し

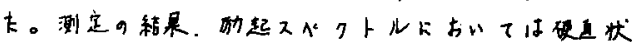
態においておよを235n m, $280 \mathrm{~nm}$. $300 \mathrm{~nm}$

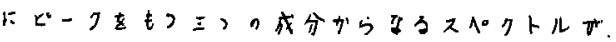

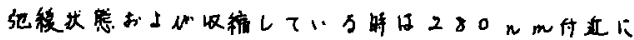

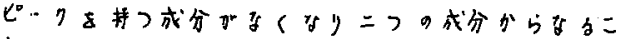
とガかガつ。

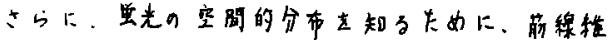

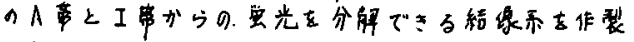

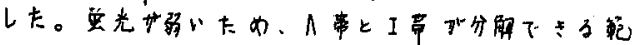

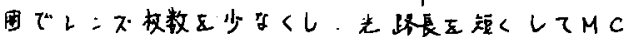
P(マ\{クロチマ:ネルプレート)により像の明了

†を增福しカメラで撮影でミるようにした。现段階

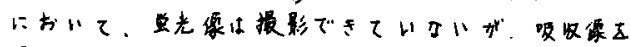
掫影することかでた。

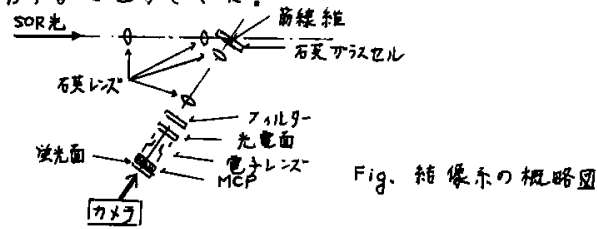

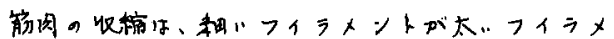

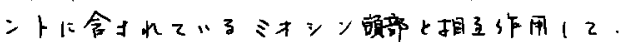
ATPを分解して、互に殿込てことによつて起:

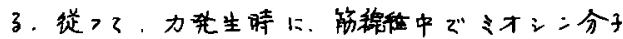

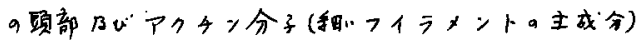
が、いか后る棈造变化を起すかと知ることは。能收 秺機楮を分子レベルで理解する上で重要である。

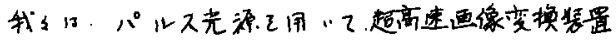

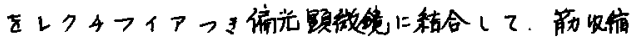

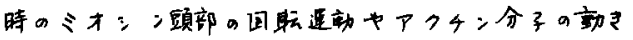

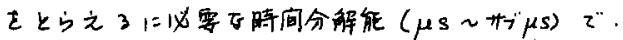

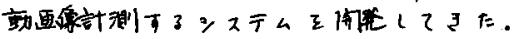

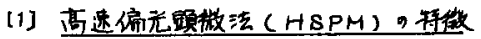

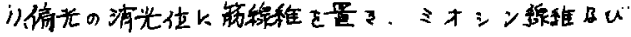

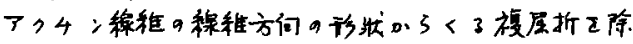

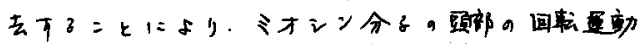

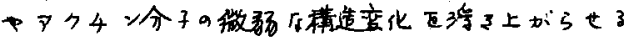
ことができる.

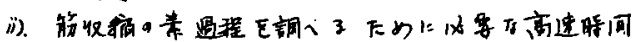

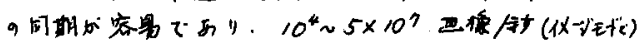

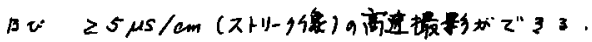

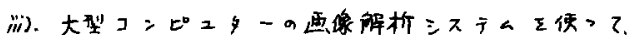

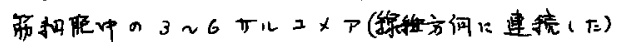

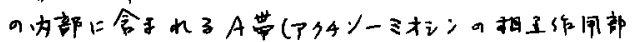

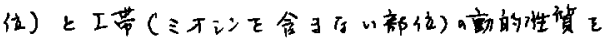

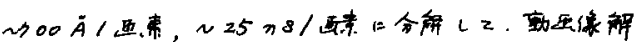
析オ了二とげでミる。

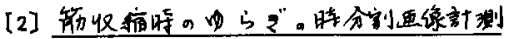

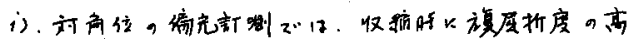

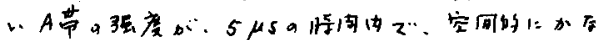

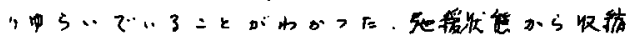

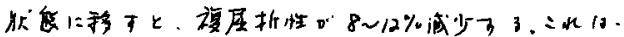

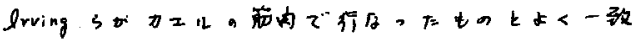
寸 $3(\sim 8.9 \%)$.

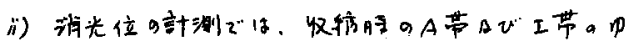

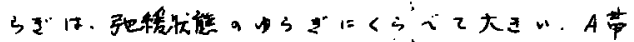

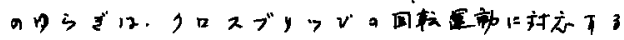

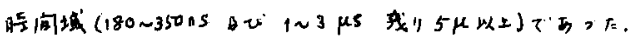

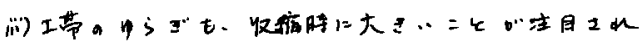

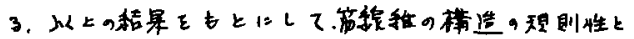

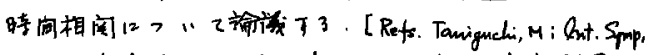

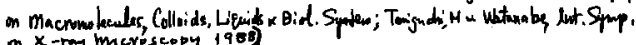


硬骨魚カサコのウキブクロ箭は著しく発逵した能

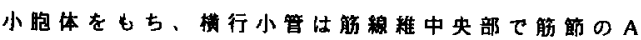

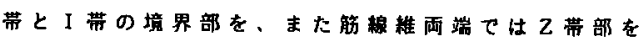

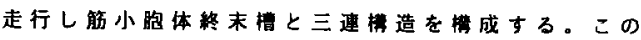

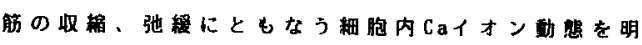
らかにするために静止時、霓気刺激による強粳時、

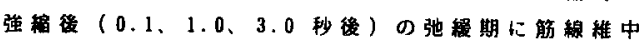
央部を急速東轺し、凍䊅狱断切片を作成し、電影下

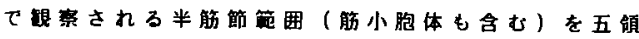
域 (2、I、A1、A2、H) に区分し、各領域てのCa惯度 をX楾マイクロアナリシス法により测定した。

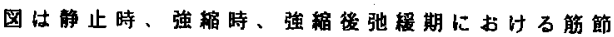
各領域の定量的元素分析の結果を示している。解止 時では、肪小胞体終末槽を含むIおよひAI領域で高

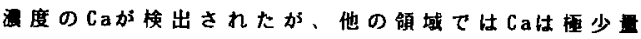
加または殆ど柣出されなかった。一方，強樎時では I、A1锁域てのCa量は掝少し、これに对応する上う な他の領域てのC、增加が钼察された。このし、分布変

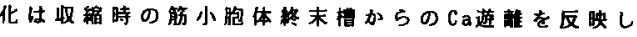
ていると考えられる。强樎後0.1秒てはCa分布に顕 着な变化はみられなかつたが、1.0、3.0徏では

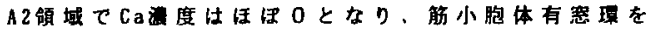

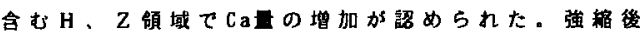

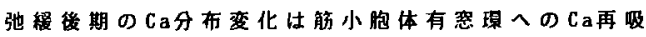
叹を示唆しているように思われる。しかし、弛程早 期における 今後の研究で明らかにする予定である。
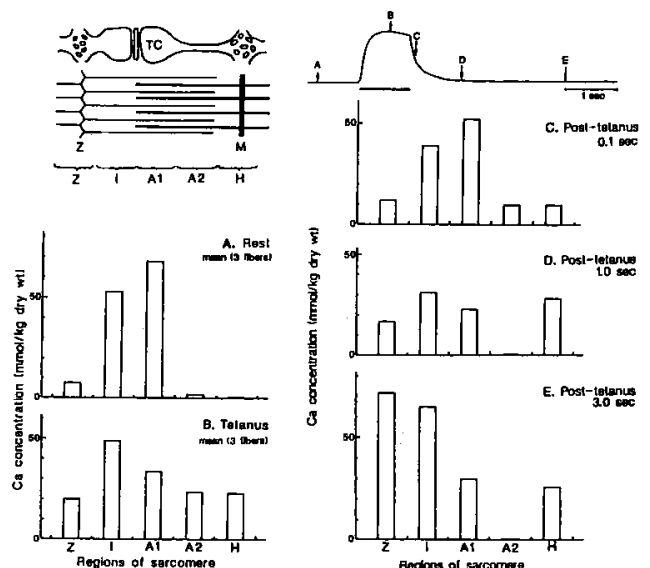

$1 \mathrm{C} 1745$

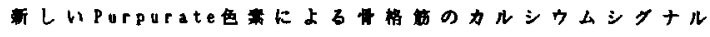

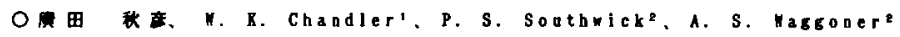

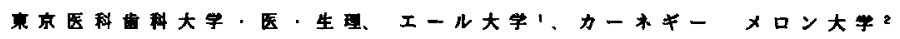

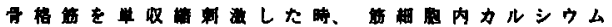

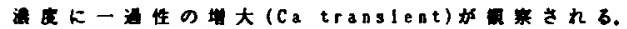

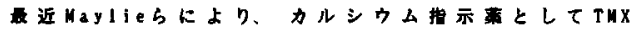

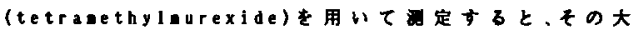

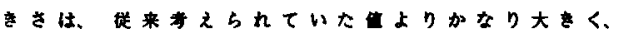

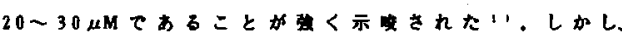

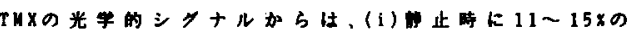

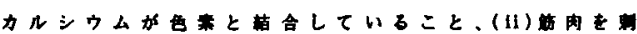

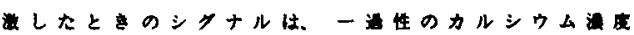

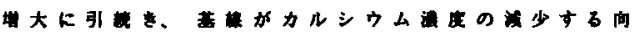

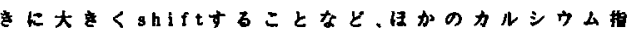

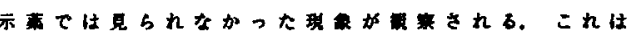

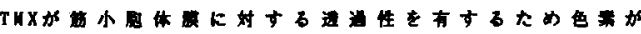

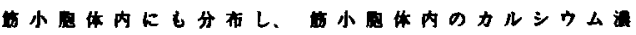

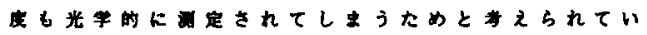

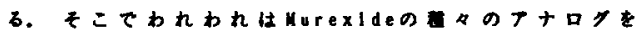

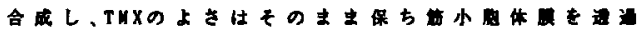

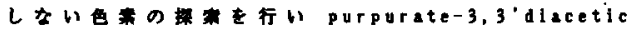

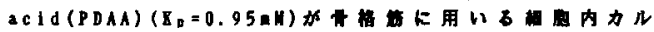

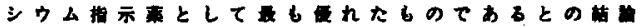
を橉た。
カエル (Bana tenporaria) 半模のcut fiber 屯をdouble-Vasel1ne-gapłェンバーに固定した

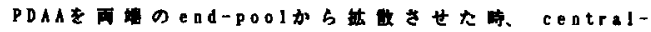

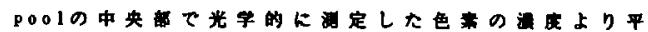

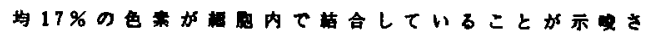

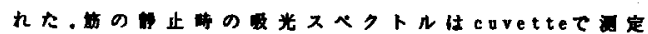

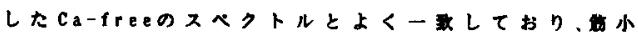

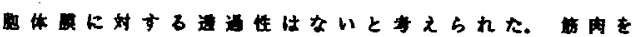

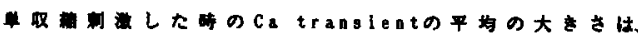

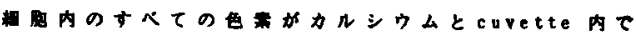

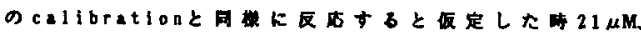

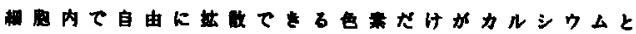

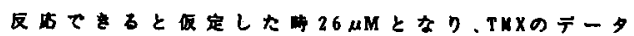

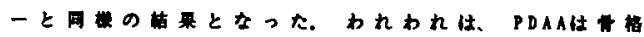

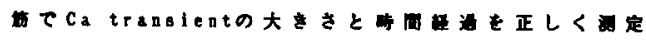

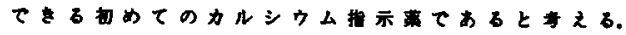

文

1. Majlie, J., Irvigs, M., Sizto, M. L. and Chandler, N. R.

J. Gen. Physlol, 89, 145-176, 1987 